\title{
Ovos e órgãos reprodutores de fêmeas de Angiostrongylus costaricensis são reconhecidos mais intensamente por soros humanos de fase aguda na angiostrongilíase abdominal
}

\author{
Eggs and reproductive organs of female Angiostrongylus costaricensis \\ are more intensely recognized by human sera from acute \\ phase in abdominal angiostrongyliasis
}

\begin{abstract}
Ana Lígia Bender ${ }^{1,2,3}$, Rafael Lucyk Maurer ${ }^{1,2,3}$, Márcia Cristina Fernandes da Silva ${ }^{1,2,3}$, Renata Ben ${ }^{1,2,3}$, Paula Barros Terraciano ${ }^{1,2,3}$, Ana Cristina Aramburu da Silva ${ }^{1,2,3}$ e Carlos Graeff-Teixeira ${ }^{1,2,3}$
\end{abstract}

Resumo O Angiostrongylus costaricensis é um nematódeo intra-arterial de roedores. O homem acidentalmente pode se infectar ao ingerir alimentos ou água contaminados. Nosso objetivo foi o de descrever as estruturas do parasita que são reconhecidas por soros humanos das fases aguda e convalescente da angiostrongilíase abdominal. O método de imunofluorescência indireta foi empregado para estudar a reatividade sobre ovos íntegros e cortes de vermes fêmeas e de larvas de primeiro estágio ( $L 1)$. L 1 também foram estudadas íntegras e depois de tratamento por sonicação. Fluorescência sempre mais intensa com soros de fase aguda foi detectada na superfície dos ovos inteiros e nos fragmentos de $L 1$ e não estava presente nem nas $L 1$ inteiras, nem em seus cortes. Uma reatividade inespecífica foi detectada na borda cuticular da cavidade geral e sobre os órgãos reprodutores. Os dados indicam que estes órgãos são fonte importante de antigenicidade.

Palavras-chaves: Angiostrongilíase. Imunofluorescência indireta. Angiostrongylus costaricensis. Imunodiagnóstico.

\begin{abstract}
Angiostrongylus costaricensisis is an intra-arterial nematode of rodents. Man may become accidentally infected through ingestion of contaminated food or water. Our objective was to describe the parasite structures recognized by human antibodies in serum samples from acute and convalescent phases of abdominal angiostrongyliasis. An indirect immunofluorescent method was employed to study reactivity on whole eggs and sections of female worms and first stage larvae (L1). L1 were also studied before and after sonication. Fluorescence, always higher with acute phase sera, was detected on the surface of whole eggs and in L1 fragments and was neither present on whole $L 1$ nor on their sections. An inespecific reactivity was seen on the cuticular border of the general cavity and reproductive organs. The data indicate the latter as a main source of antigenicity.
\end{abstract}

Key-words: Angiostrongyliasis. Indirect immunofluorescent. Angiostrongylus costaricensis. Immunodiagnosis.

O Angiostrongylus costaricensis é um nematódeo intra-arterial de roedores, causador da angiostrongilíase abdominal e com ampla distribuição geográfica nas Américas ${ }^{9}$. O homem é infectado acidentalmente quando ingere comida ou água contaminados com larvas de terceiro estágio presentes no muco secretado por moluscos terrestres, seus hospedeiros intermediários ${ }^{8}$.

A infecção humana é acompanhada de intensa reação inflamatória, que retém grande parte dos ovos nos tecidos, impedindo a liberação de larvas de primeiro estágio, de modo semelhante ao que ocorre nos roedores. O acometimento inflamatório é intestinal - principalmente íleo-cecal, com dois padrões fundamentais de lesões macroscópicas: tumoral e isquêmico-congestivo ${ }^{4}$. Não há tratamento medicamentoso recomendado, pois as drogas de ação tecidual testadas em modelo experimental podem agravar o quadro ao induzir migração errática dos vermes e desencadear tromboses arteriais ${ }^{510}$. No Brasil, a

\footnotetext{
1. Laboratório de Parasitologia Molecular do Instituto de Pesquisas Biomédicas da Pontificia Universidade Católica do Rio Grande do Sul, Porto Alegre, RS 2. Laboratório de Biologia Parasitária da Faculdade de Biociências da da Pontificia Universidade Católica do Rio Grande do Sul, Porto Alegre, RS. 3. Programa de Pós-Graduação em Biociências da Pontificia Universidade Católica do Rio Grande do Sul, Porto Alegre, RS

Auxílio Financeiro: PUCRS, CNPq e FAPERGS.

Endereço para correspondência: Dr. Carlos Graeff-Teixeira. IPB, $2^{\circ}$ andar, Av. Ipiranga 6690, 90610-000 Porto Alegre, RS.

Telefax:513320-3312

e-mail:graeteix@pucrs.br

Recebido para publicação em 30/6/2003

Aceito em 18/5/2003
} 
maioria dos casos ocorrem nos Estados de Paraná, Rio Grande do Sul, Santa Catarina e São Paulo. Um estudo epidemiológico no Rio Grande do Sul mostrou que a angiostrongilíase é uma doença sazonal que afeta adultos e crianças ${ }^{7}$. Contudo, poucos pacientes são diagnosticados no Sul do Brasil, se comparado ao que ocorre na Costa Rica (América Central), onde a angiostrongilíase é considerada um problema de saúde pública ${ }^{9}$. Assim, um método sorológico é instrumento importante para estudos epidemiológicos e aplicação clínica. Um teste imunoenzimático foi padronizado por Graeff-Teixeira ${ }^{4}$, permitindo a documentação da reatividade cruzada. Análises da cinética da resposta humoral humana através do método de imunoeletrotransferência mostraram: a) intensa reatividade cruzada; b) complexidade do antígeno bruto de fêmea e ausência de padrão específico com revelação de lgM, IgG1-2-3-4 e lgE (dados não publicados).

Diante das dificuldades de padronização de testes imunológicos com boa sensibilidade e especificidade, a identificação de componentes antigênicos estágioespecíficos indicadores de fase aguda poderiam auxiliar no aprimoramento dos métodos de diagnóstico. A imunofluorescência indireta é um método extremamente sensível, que permite a identificação de estruturas do A. costaricensis que apresentem maior antigenicidade na fase aguda, bem como melhor especificidade.

\section{MATERIAL E MÉTODOS}

Manutenção do ciclo: os isolados Santa Rosa e Nova Itaberaba de $A$. costaricensis são mantidos em laboratório, em camundongos Swiss e C57BL6. As fezes dos roedores infectados são examinadas utilizando-se o método de Baermann, pelo qual são recolhidas as larvas L1. Após a centrifugação, as L1 são contadas com o auxílio de estereomicroscópio e posteriormente utilizadas para infectar Biomphalaria glabrata, onde se completa o ciclo de 28 dias para a obtenção da larva L3. A B. glabrata é digerida com ácido clorídrico $0,7 \%$ e pepsina $0,03 \%$ (Sigma $\mathrm{P} 7125$ ), a $37^{\circ} \mathrm{C}$ por uma hora, para coleta das larvas L3. Estas são inoculadas em camundongos para a manutenção do ciclo (10 a 15 L3 por animal) e/ou obtenção de vermes adultos (inoculação de 30 L3 por animal) utilizados como substrato para análise.

Amostras: foram utilizadas amostras de três indivíduos com diagnóstico de angiostrongilíase, confirmado por exame anátomo-patológico provenientes da soroteca de referência do Laboratório de Parasitologia Molecular do IPB/PUCRS, mantidas a $20^{\circ} \mathrm{C}$. Essas amostras foram coletadas em dois momentos diferentes pós-infecção: na fase aguda, até trinta dias do início dos sintomas (PA = positivo na fase aguda) e na fase de convalescença, noventa dias após o início dos sintomas ( $P C=$ positivo na fase de convalescença). Além dessas, foram usadas duas amostras oriundas de indivíduos portadores de outras parasitoses (CE = controle de especificidade): um paciente com diagnóstico de hidatidose e outro com sorologia positiva para toxocaríase. A amostra de soro de um indivíduo clinicamente sadio com reatividade muito baixa à pesquisa de anticorpos para angiostrongilíase por método imunoenzimático foi utilizada como controle normal $(\mathrm{CN})^{2}$.

Preparo de antígenos. a) Ovos: purificados a partir da solução salina na qual vermes adultos foram mantidos a $37^{\circ} \mathrm{C}$ por 48 horas, e a concentração foi ajustada para 100 ovos/ $\mu \mathrm{L}$. A suspensão foi lavada duas vezes em solução salina $0,9 \%$ com centrifugação durante cinco minutos, a $850 \times \mathrm{xg}$. Uma amostra PA, duas amostras CE e uma amostra CN foram diluídas a 1/200 (concentração determinada por experimento de titulação) na suspensão de ovos $(2 \mu \mathrm{L}$ soro $+398 \mu \mathrm{L}$ de suspensão de ovos) e incubadas em banho de água a $37^{\circ} \mathrm{C}$ por 30 minutos. Após a incubação, os ovos foram lavados duas vezes com $600 \mu \mathrm{L}$ de tampão salina fosfato (PBS) e centrifugados por 5 minutos a $850 \times$ g. Centrifugou-se novamente por cinco minutos a $850 \mathrm{xg}$ e ressuspenderamse os ovos com 200 $\mu \mathrm{L}$ de conjugado fluorescente antihumano (bioMèrieux, Rio de Janeiro, Brasil) diluído a 1/ 500 marcado com isotiocianato de fluorescenína (FITC). O título de conjugado foi escolhido após titulação, empregando-se células Hep-2 e cortes histológicos de rim de rato, com a diluições seriadas do conjugado sobre amostras-padrão positiva e negativa para estes substratos. Incubou-se por 45 minutos em banho-maria a $37^{\circ} \mathrm{C}$. Depois repetiram-se três ciclos de lavagem com $600 \mu \mathrm{L}$ de PBS e centrifugação por 5 minutos a $850 \times \mathrm{xg}$. Ao final, o botão de ovos foi ressuspenso com PBS e os ovos foram observados entre lâmina e lamínula com aumento de 400x em microscópio de fluorecência Olympus Provis AX 70 e analisados em Citômetro de Fluxo FacsCalibur.

$\mathrm{Na}$ citometria de fluxo foram contados 5 mil eventos (cada evento $=1$ ovo). Não foi possível a análise por citometria com um número significativo de amostras, em função da quantidade de ovos requerida para o experimento. Assim, utilizamos o teste KS (KolmogorovSmirnov) para comparar as fluorescências médias.

b) Larvas L1: suspensas em concentração ajustada para 100 larvas $L 1 / \mu \mathrm{L}$, foram lavadas duas vezes por 5 minutos cada, a $850 \times$ g e com solução salina de $0,9 \%$. Parte desta suspensão de larvas $L(100 \mu L)$ foi incluída em gel (Tissue Freezing Medium, cat. 0201 08926, Leica Instruments, Nussloch, Germany) para corte em criostato. Outra parte foi submetida a tratamento com ultrasom, visando romper cutículas e membranas. Os cortes congelados e a preparação sonicada foram submetidos à reação de imunofluorescência (RIF) como descrito anteriormente, exceto por um volume maior nos ciclos de lavagem com $800 \mu \mathrm{L}$ de PBS.

As larvas incluídas em gel foram mantidas a $-20^{\circ} \mathrm{C}$, até serem feitos os cortes de seis micrômetros em criostato Shandon (Inglaterra). Os cortes foram 
colocados em lâminas revestidas com ovalbumina, fixados em etanol absoluto por 10 minutos e processados pelo método de RIF, conforme descrito anteriormente. Após secarem à temperatura ambiente, as lâminas foram montadas com glicerina alcalina, para observação ao microscópio.

A lise por ultrassom de $500 \mathrm{~mL}$ da suspensão de larvas L1 foi realizada com o equipamento Vibracell 7502 (Sonics, Newtown, CT USA) amplitude de 30\% em dois ciclos de 120 segundos, em banho de gelo. Exceto pelas condições de centrifugação nos passos de lavagem (10.000xg, 3 minutos), o processamento da RIF ocorreu como acima descrito.

c) Vermes: as fêmeas foram lavadas em solução salina $0,9 \%$ e incluídas em gel. No período de estudo não foi possível dispor de vermes machos. Os cortes histológicos de cinco micrômetros foram feitos em criostato Shandon (Inglaterra), aplicados sobre lâmina revestida com ovalbumina e fixados com etanol absoluto por 10 minutos. Os cortes foram mantidos a $-20^{\circ} \mathrm{C}$ até o processamento pela técnica de RIF.

\section{RESULTADOS}

A microscopia óptica de fluorescência demonstrou intensa fluorescência homogênea apenas na superfície dos ovos incubados com soros PA, (Figura 1), o que foi demonstrado também na análise em citometria de fluxo. A amostra de soro PA e as duas amostras de reatividade cruzada (CE) apresentaram diferença de fluorescência significativa em relação à amostra de indivíduo não parasitado $(\mathrm{CN})$, com $\mathrm{p} \leq 0.001$. Apresentou também diferença significativa a fluorescência média da amostra PA em relação a cada uma das duas amostras CE analisadas, com $p \leq 0,001$ (Figura 2).

Não foi observada fluorescência na membrana externa de larvas L1 íntegras ou em cortes, em nenhuma das amostras de soro testadas. Nas larvas tratadas pelo ultrasom foi demonstrada reatividade com amostra PA, a fluorescência observada foi menos intensa com amostra CE e ausente com CN (Figura 3).

Nos cortes de vermes testados com amostras de fase aguda, foi observada reatividade nas estriações transversais da cutícula (também observada em alguns cortes analisados com soro de indivíduo não parasitado), fluorescência ao longo do contorno da cavidade geral, ausência de reatividade em tubo digestivo e reatividade em tubo reprodutor, que aumentava à medida em que os cortes feitos eram mais próximos da extremidade caudal .

Nos cortes analisados com soros de fase de convalescença (PC), observou-se que os padrões de reatividade mantinham similaridade aos da fase aguda, com discreta diminuição na intensidade de fluorescência observada no tubo reprodutor.

Nos cortes analisados com soros CE, foi observada reatividade do contorno da cavidade geral, que se mantinha nos cortes proximais e distais do verme e reatividade na superfície externa da cutícula em alguns cortes. No tubo reprodutor observou-se reatividade de menor intensidade ou ausência de reatividade interna nos cortes proximais do verme (Figura 4).

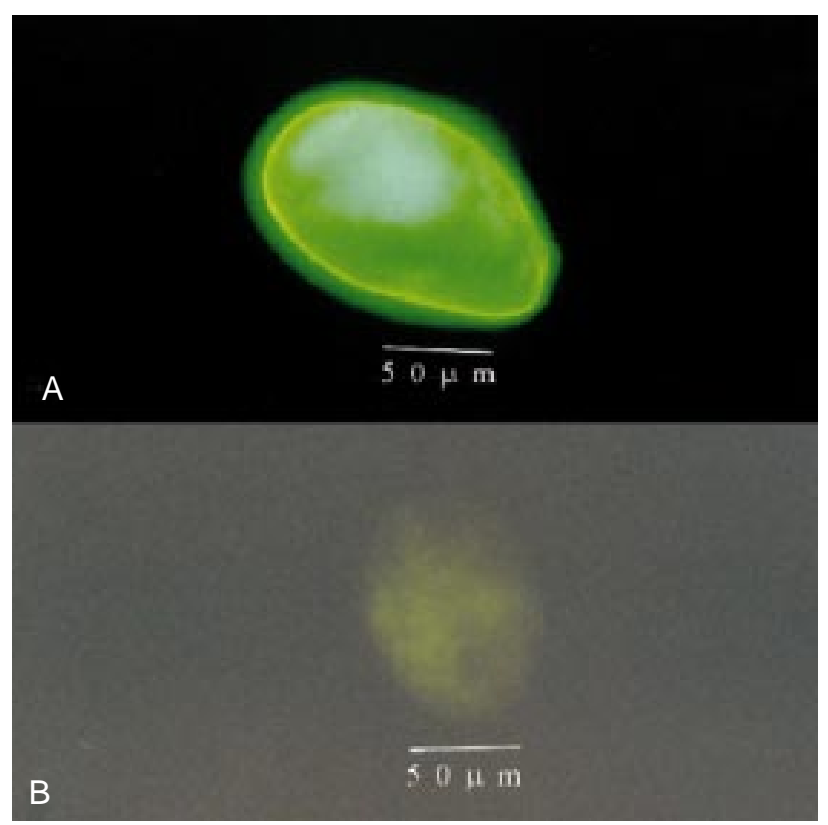

Figura $1-E m$ A) ovo de A. costaricensis apresentando intensa reatividade de membrana com amostra positiva de fase aguda e em $B$ ) ausência de reatividade frente a amostra controle normal (400x). 


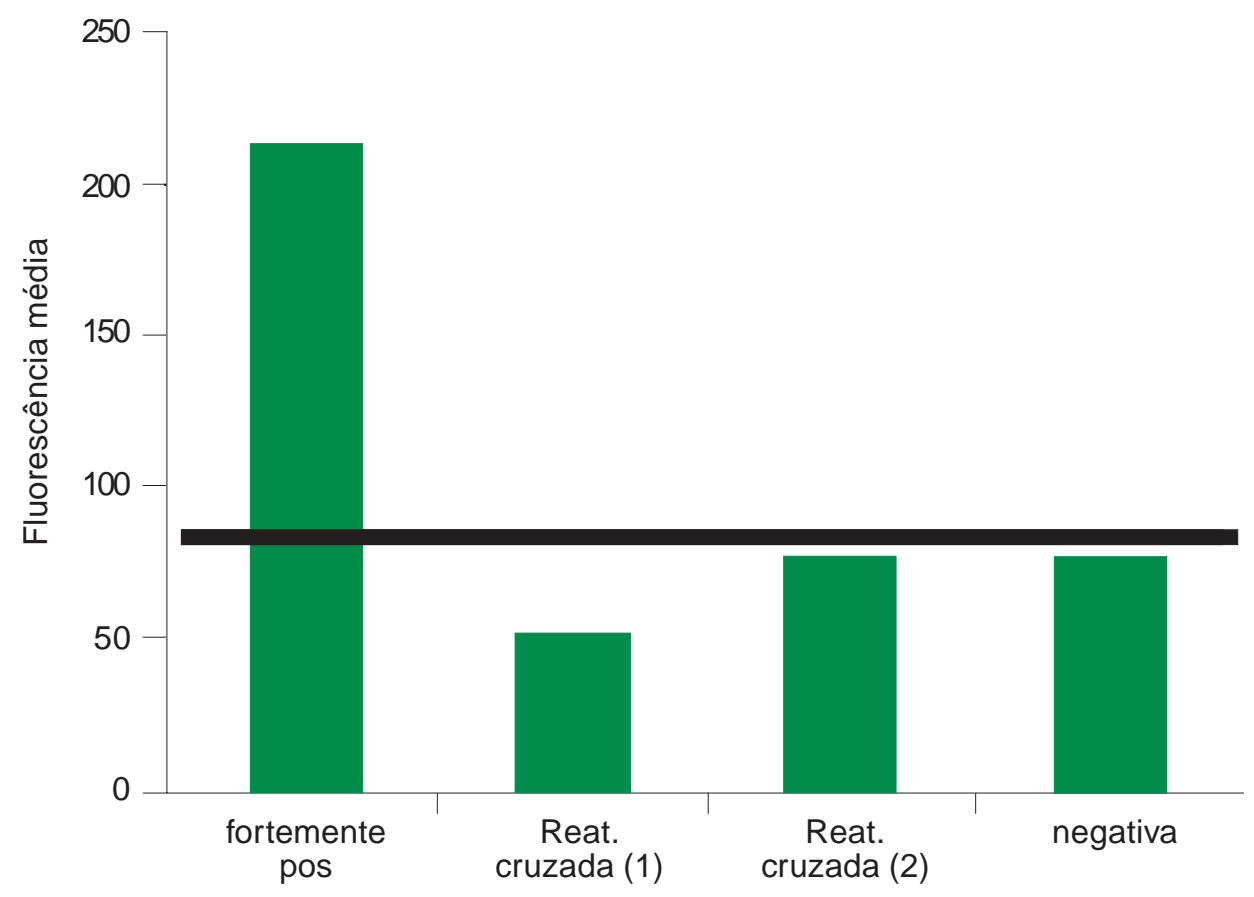

Figura 2 - Gráfico da análise por citometria de fluxo da reatividade dos ovos de A. costaricensis frente ao soro positivo de fase aguda, controle de especificidade 1 e 2 e controle normal.

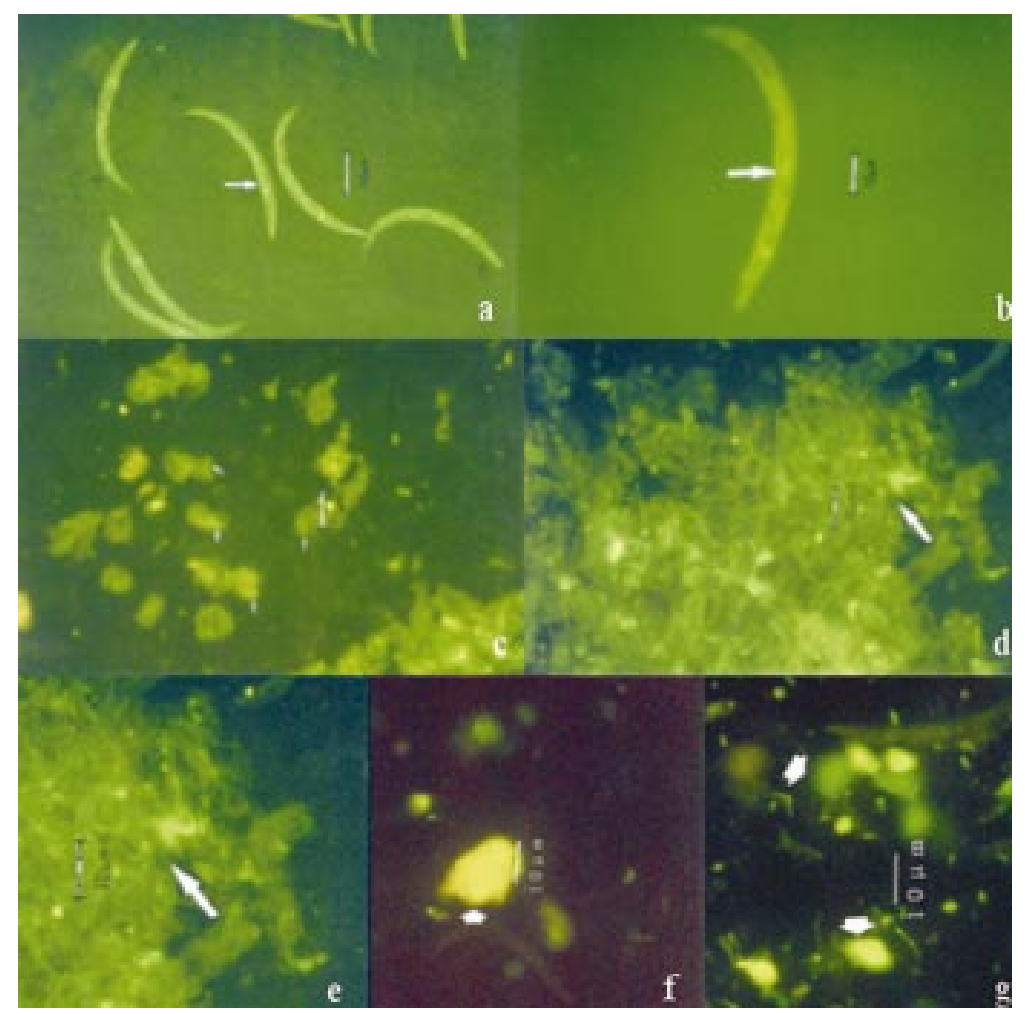

Figura 3 - Em (a) larvas L1 de A. costaricensis íntegras analisadas com soro positivo de fase aguda (PA) e em (b) com soro controle de especificidade (CE); em $(d)$ com soro CE $(A=400 x)$. Análise de larvas tratadas pelo ultrasom com soro controle normal em (e), soro CE em (f) e com soro PA em (g). 


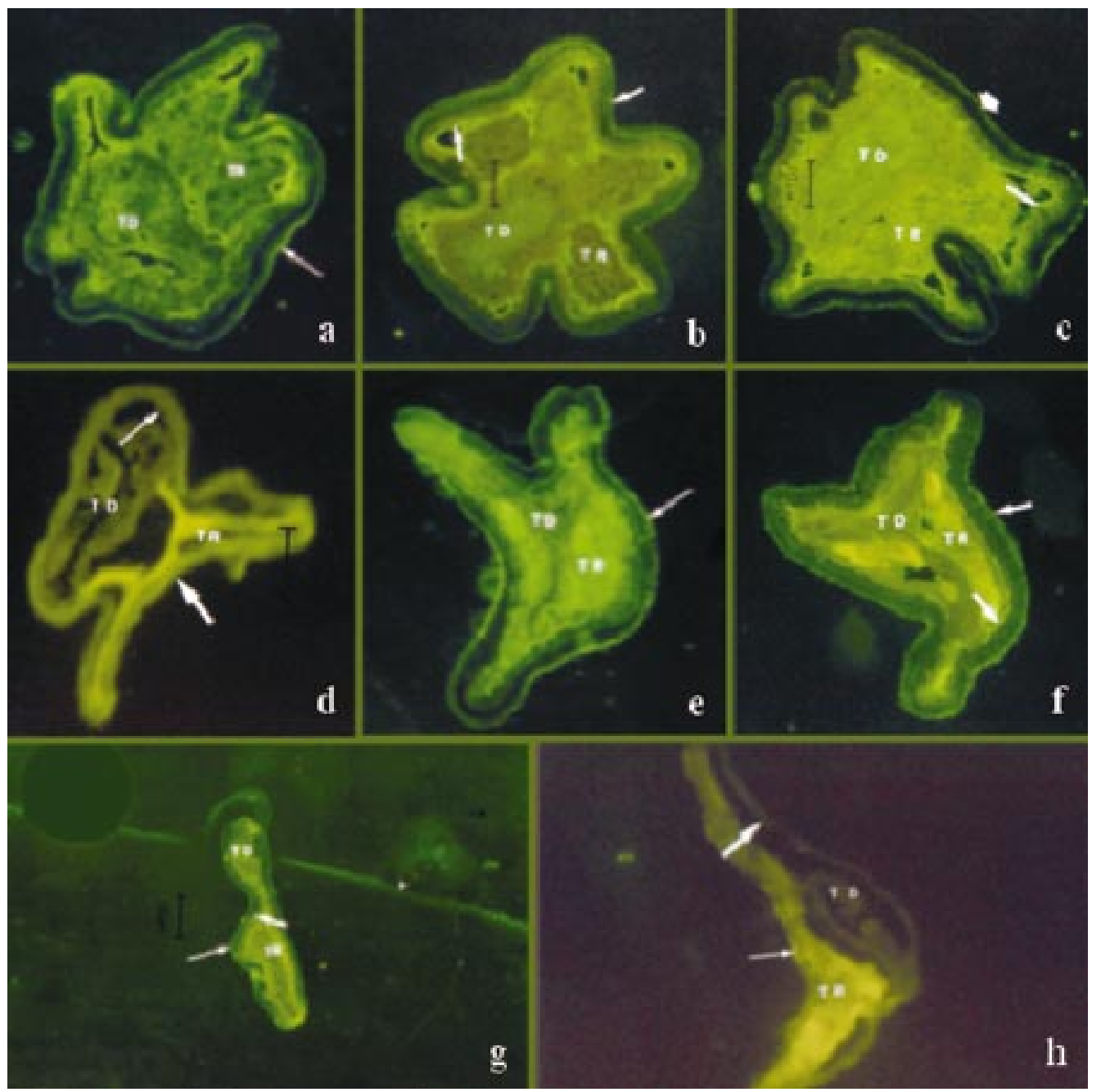

Figura 4 - Cortes da região anterior ( $a, b, c, d)$ e posterior (e,f,g,h) de vermes fêmea do A. costaricensis analisados com soro positivo de fase aguda (PA), em (a) e (e); positivo da fase de convalescência, $P C$, em (b) e (f); controle de especificidade, (CE) em (c) e (g) e controle normal, CN, em (d) e (h). A cutícula e o contorno da cavidade geral estão indicados por setas. $T D=$ tubo digestivo e $T R=$ tubo reprodutor. $(A=400 x)$.

\section{DISCUSSÃO}

A história do desenvolvimento de imunodiagnóstico em infecções helmínticas inclui esforços permanentes de purificação e avaliação de antígenos espécie-específicos. Antígenos purificados por cromatografia, que removem antígenos responsáveis pela reatividade cruzada, aumentam a especificidade dos testes diagnósticos, comparativamente aos extratos de antígenos brutos dos parasitas ${ }^{13}$.

O antígeno bruto é uma mistura muito complexa. Assim, direcionar a purificação de componentes é muito importante. A infecção por Angiostrongylus costaricensis, bem como pelo $A$. cantonensis, induz à formação de anticorpos de reatividade cruzada a outros parasitas ${ }^{14}$. No experimento aqui relatado observou-se que o padrão de reatividade ao contorno da cavidade geral e ao tubo reprodutor estava presente - salvo variações na intensidade de fluorescência - quando testados soros das fases aguda e convalescente e nas amostras utilizadas como controles de reatividade cruzada, demonstrando-se o predomínio de resposta humoral inespecífica.

Devido às dificuldades em manter os cortes fixados à lâmina durante o teste de imunofluorescência indireta, foram utilizadas lâminas com revestimento de ovalbumina, o que poderia ter ocasionado maior reatividade de fundo back-ground em torno do corte, mas que não prejudica as principais conclusões do estudo. A fluorescência em torno das estriações transversais da cutícula foram observadas também em alguns cortes analisados com soro do controle normal. 
A intensa reatividade observada nos ovos (tanto íntegros quanto rompidos) e no tubo reprodutor das fêmeas analisadas demonstra que a antigenicidade do A. costaricensis está bastante associada à maturação do tubo reprodutor. Geiger e colaboradores ${ }^{2}$ relataram o aumento nos níveis de anticorpos específicos ao A. costaricensis do décimo quarto ao vigésimo primeiro dia após a infecção em diante, especialmente para lgG1, em infecção experimental murina ${ }^{13}$. Este aumento coincide com a produção de ovos pela fêmea e com a produção e migração de larvas $L 1$ através dos tecidos intestinais, como descrito por Mota e Lenzi ${ }^{11}$.

Extratos do tubo reprodutor já foram avaliados por eletroforese em gel de poliacrilamida e imunoeletrotransferência para $A$. costaricensis (dados não publicados), sendo ainda as misturas muito complexas e sem evidências de componentes específicos. Há a possibilidade de que os epítopos mais específicos sejam minoritários, requerendo-se sua purificação e concentração para avaliação da utilidade diagnóstica. Não foram obridas evidências da localização destes epítopos no estudo.

Oku e col $^{12}$ relataram a precipitação de anticorpos em torno das larvas de terceiro estágio e vermes adultos imaturos, mas não encontrou a formação do precipitado nas larvas de primeiro estágio de outro metaestrongilídeo prevalente na Ásia e Oceania - o $A$. cantonensis - fato também observado em nosso experimento, o que poderia ser decorrente da presença de uma bainha envolvendo a L1, sem comunicação com o meio externo ${ }^{8}$. Além disso, a ausência de reatividade interna das $\mathrm{L} 1$ em corte pode estar associada à existência de antígenos sequestrados e somente expostos suficientemente no material antigênico quando tratado com ultrasom. É possível também que as moléculas antigênicas sejam pouco expressas nessa forma larvar. Todas estas possibilidades estão de acordo com a variabilidade da expressão de moléculas, especialmente de superfície, nos diferentes estágios de um parasita, o que pode ter papel importante nos mecanismos de escape que permitem a migração das larvas, mesmo em hospedeiros não habituais ${ }^{1}$.

Em conclusão, os dados deste trabalho indicam que grande parte da antigenicidade do A. costaricensis está localizada nos órgãos reprodutores, que poderiam ser fonte de antígenos purificados para o diagnóstico da fase aguda da angiostrongilíase abdominal.

\section{REFERÊNCIAS BIBLIOGRÁFICAS}

1. Duangporn N, Ishii A I, Terada M, Kino H, Sano M. Humoral immune responses in mice infected with Angiostrongylus costaricensis. Serodiagnosis and Immunotherapy in Infectious Diseases 3 51-56, 1989.

2. Geiger SM, Graeff-Teixeira C, Soboslay PT, Schulz-Key H 1999. Experimental Angiostrongylus costaricensis infection in mice: immunoglobulin isotype responses and parasite-specific antigen recognition after low-dose infection. Parasitology Research 85: 200-205.

3. Geiger SM, Laitano AC, Sievers-Tostes C, Agostini AA, SchulzKey $\mathrm{H}$, Graeff-Teixeira C. Detection of the Acute Phase of Abdominal with a Parasite-specific IgG Enzyme Linked Immunosorbent Assay. Memórias do Instituto Oswaldo Cruz 96 (4) 515-518, 2001.

4. Graeff-Teixeira C. Contribuição ao conhecimento da epidemiologia da angiostrongilose abdominal no sul do Brasil. Tese de Doutorado, FIOCRUZ/ Instituto Oswaldo Cruz, Rio de Janeiro, 1991.

5. Graeff-Teixeira C, Agostini AA, Camillo-Coura L, Ferreira-da-Cruz MF. Soroepidemiology of abdominal angiostrongyliasis: the standardization of an immunoenzymatic assay and prevalence of antibodies in two localities in Southern Brazil. Tropical Medicine International Health 2: 254-260, 1997.

6. Graeff-Teixeira C, Camillo-Coura L, Lenzi HL. A Histopathological criteria for diagnosis of abdominal angiostrongylosis. Parasitology Research 77: 606-611, 1991.

7. Graeff-Teixeira C, Camillo-Coura L, Lenzi HL. Clinical and epidemiological aspects of abdominal angiostrongyliasis in southern Brazil. Revista do Instituto de Medicina Tropical de São Paulo 33: 373-378, 1991.

8. Morera P. Life history and redescription of Angiostrongylus costaricensis Morera and Cèspedes, 1971. American Journal Tropical Medicine and Hygiene 22:613-621, 1973.

9. Morera P. Abdominal angiostrongyliasis. In Clinical Medicine Volume 3 (ed Spittel Jr.) Harper \& Row, Philadelphia, p. 1-4, 1986.

10. Morera P, Bontempo I. Accion de algunos antihelminticos sobre Angiostrongylus costaricensis . Revista Medica Hospital Niños Costa Rica 20: 165-174, 1985.

11. Mota EM, Lenzi HL. Angiostrongylus costaricensis life cycle: a new proposal. Memórias do Instituto Oswaldo Cruz 90: 707-709, 1995.

12. Oku I, Kamiya M. Circumoval and circumlarval precipitate reactions of Angiostrongylus cantonensis. Japanese Journal Veterinary Research 32:23-39, 1984.

13. Welch JS, Dobson C. Immunodiagnosis of parasitic zoonoses: comparative efficacy of three immunofluorescense tests using antigens purified by affinity chromatography. Transactions of the Royal Society of Tropical Medicine and Hygiene 72: 282-288, 1978.

14. Yen C, Chen E, Kojima S, kobayashi M. Preparation of monoclonal antibody against Angiostrongilus cantonensis antigen. Southeast Asian Journal of Tropical Medicine and Public Health 20: 119124, 1989. 